\title{
BERNHARD WEISS AND THE NEW TESTAMENT.
}

\author{
By CASPAR RENé GREgory, \\ Leipzig.
}

Scholars are continually tantalized by all manner of announcements touching the birthday festivals of men whom they delight to honor, announcements that reach them a month or six weeks after the happy day, at a time at which they can either no longer send their congratulations, or at best can only send them in a limping way. Besides, even where the theological reader does not feel inclined to venture a letter of good wishes, he likes to know of the day beforehand, and to be able on the day to think of its interest for him and for theology in general. The great scholar whose name stands at the head of this article is one of those who draw upon the feelings of an extremely wide circle of men, men that have sat at his feet in one or other of the universities at which he has taught, or, and these are still more numerous, that have devoured the books written by him. It will therefore give pleasure to his many admirers in America to learn that he is soon to celebrate his seventieth birthday, and to think that they can, according to their fancy, send him word of their thoughts of him, or can mark the day for themselves and their immediate surroundings. Professor Bernhard Weiss, of the University of Berlin, has perhaps studied the New Testament in some respects more thoroughly than any other living man. There are two or three who stand near him in this respect, but they have, after all, given their thoughts free play in other directions, or have not been able to reach the same amount of work that he has been so happy as to accomplish. Nor is it probable that his work is by any means at an end, humanly speaking. The writer had the privilege, a few weeks ago, of doing ten hours' work with him, and found that his crispness and freshness in seizing a thought and in formulating it were still such as might excite the envy of younger men. 
It is worth while at a milestone like this to look back over the life and work of the leader, and to sum up the results attained, so that we may the more vividly feel and express our sense of thankfulness to him. Bernhard Weiss was born on the twentieth of June, I 827, at Koenigsberg, that eastern and northern city of Germany that reminds us of Kant, and that in spite of its Labradorian latitude rivaled New York in the sunstrokes of the summer of 1896 . His family showed the frequent union between theology and the school that is found all the world over and especially in Germany. His great grandfather was a teacher in Silesia, and his grandfather was a clergyman and teacher at Koenigsberg. His father was a councillor of the Consistory at Koenigsberg. We must remember that with his grandfather we reach far back into the religious movements of the closing eighteenth century. His grandfather was a rationalist, whereas his father became one of the most zealous champions of the returning piety, a very severe man, a man of an enormous power of work (we shall find the same power in the son), a Christian who leaned somewhat towards a pietistic cast of religion, and withal a man who had a strong sense of humor. That was a good field for the planting of a theologian who was to stand in the hard battles of these latter days. If we remember the date and the fact that but few years had passed since the Corsican devastator had wasted and oppressed and insulted Prussia, it is easy to see that a child growing up at that day would have to endure hardness in many ways, and would early learn to work. The school-days over he had at once to support himself by giving lessons, and the material care for his family, for the old home, lay upon him until the time of his moving to Kiel. But we anticipate. He studied at Koenigsberg and then a short time at Halle and finally at Berlin. At the age of twentyfive he habilitated, as the phrase goes, that is to say, he offered the necessary dissertation and passed the colloquium or examination and the other formalities for gaining permission to become a member of the teaching body of the University of Koenigsberg, and he thus became what is called a privatdocent of theology. A privatdocent can lecture as much as he pleases. The lecture 
rooms of the university are open to his use, and his lectures are announced in the university catalogues and on the university bulletin boards. He has a right to the fees for the lectures held by him, but it must be remembered that the older professors are likely to have the most of the students, especially as they also have more influence in every way upon the further course of the students. A privatdocent has to struggle for all he gets, and he cannot dream of receiving a salary. Now, however, in some cases the government gives a stipendium to privatdocents who do well. In his thirtieth year, in the year 1857 , he was appointed as extraordinary professor. An extraordinary professor may receive a small salary from the government, if the minister of public instruction is satisfied with him. It is, of course, then easy to understand how hard he had to work to bear the burden that lay on him. He taught at the University, that is to say, he held his lectures there, but at the same time he gave courses of religious instruction in several schools, and for a time he was division chaplain in the army. In the year 1859 he married, and these varied occupations continued.

Now that we have arrived at the beginning of his own family, let us turn back for an instant and ask what influences, outside of the already mentioned family influence, had thus far especially affected him; for the personal associations of a man usually determine or conversely betoken to no small extent his aims and his longings, his likes and his dislikes, his weaknesses and his strength. He was rich in a delightful circle of young friends of both sexes that found a common interest, not only in literary and æsthetic occupations and discussions, but also and particularly in religious contemplation and exchange of thought. One of these youthful friends was the historian Georg Voigt, for many years a professor at Leipzig, who died a few years ago. The letter which stands like a preface to Weiss's Life of Jesus shows how intimately they were bound to each other. In that letter, written fourteen years ago, Weiss refers to their common studies in youth and to their dream of some day teaching in the same university, a pleasure that they never were to enjoy. One token of their studies exists in the translation of Thompson's 
Seasons that they made together in pursuit of their English likings. The theological professors who had the most influence upon his studies were probably Neander, Dorner, and Tholuck. But there were other friendships and other interests than the merely scientific ones. He stood very close to Wichern, and once, towards the end of the forties, made a long journey with him.

It was part and parcel of this friendship that Weiss from the first had a deep interest in what is called in Germany "Inner Mission," a combination of the American Home Missions with every description of care for the poor, ignorant, sick, and in any way needy. Thus his theological thoughts did not run in a dead rut of books and libraries, and pen and ink, and university discussions, but were as closely bound up with the life of the church as was possible - with the life of the church and not merely with the organs of ecclesiastical authority. As a student he busied himself with these living questions and with these living deeds. Of his friends out of these early years we may further mention Oldenberg who renewed and deepened if possible the old Koenigsberg friendship when they were both again in one city, in Berlin. The lamented church historian, W. Moeller of Kiel, was also one of his warmest friends. They knitted together during a journey in Switzerland in the year 1848. This will be enough for the present in reference to the person of the rising professor as he begins to unfold his wings. Let us turn to his literary productions.

In the year 1855 appeared his book on the Petrine Doctrinal Conception, a book that was honored by much attention, and that not only on the part of friends but also on the part of opponents. It is especially interesting to observe how Ferdinand Christian Baur, the eminent Tübingen professor, criticised it. In the Tübingen Theologische Jahrbiicher for I856, pp. 193-240, he discussed it very thoroughly. The most striking thing in the review was the light it threw upon Baur's way of thinking Everyone knows how Baur determined by examination of the New Testament writings precisely what each writer had in mind as he wrote, precisely what party he belonged to, and precisely what the special purpose of the particular book was. Laudable 
as Baur's thought and industry were, he went too far in his divination and found out parties that did not exist. Now it is really amusing to see how Baur applied the same plan to Weiss's book and discovered a plan of operations in it. And the matter grew better still with one of Baur's friends, for he attributed on the same principle to Weiss an opinion that Weiss did not in the least cherish, and when Weiss declared that he did not think anything of the kind, the critic insisted upon it that he did. One could imagine Baur's saying: "I can tell just what an apostle or a Christian in the first century is at, when he writes a book, and it is twice as easy for me to tell what this privatdocent in Kiel thinks when he writes." But nevertheless Weiss was unable to agree with him and we must conclude, on the contrary, that if Baur was so thoroughly unable to tell what the purpose of a privatdocent of his own day was, he was a hundred times less able to tell what the apostles and the Christians of the first centuries thought. But we are wandering. In the year I 859 Weiss followed up the Petrine volume by one on the epistle to the Philippians, and in the year 1862 by one on the Doctrinal Conception of John. This was his last book as extraordinary professor, for the next year, I863, he was appointed ordinary or full professor at the University of Kiel. The next book that appeared was his Biblical Theology of the year I868, the completion for the whole New Testament of the doctrinal review begun in his Petrine Doctrinal Conception thirteen years before. This Biblical Theology remains today in its later editions one of the most useful works in that department. Let no one, however, take it up under the impression that he has before him a conversational, elementary, fluently written treatise on the thoughts that Weiss conjured up to himself about what the New Testament writers might have said. It is a thorough presentation of all the material that the New Testament contains, ordered according to the approximate time of the composition of the books; though without tearing apart the writings that belong together. It presupposes in the reader the intention to read with his New Testament open and to look at each text that is cited, if he does not know it by heart. In short it is a book for 
profound occupation with the subject and not one to be taken up like a novel after dinner.

His next books were two large ones of the same solid character. The relation of the synoptic gospels, Matthew, Mark, and Luke, to each other is of vital moment for the due understanding of the gospels. Treatise after treatise has been written upon the subject during the last hundred years, but none has been more exhaustive and more instructive for the theological world than the books and the articles of Weiss. The volume in the year 1872 took up the Gospel according to Mark and its Synoptic Parallels. To this day it remains the best introduction for a careful scholar to the intricacies of these discussions. The different accounts are put each in its own column, and then the fragments out of the various sources, so far as at present they can be separated, are made distinct by certain kinds of type. The whole is then clearly explained. The printing in the different kinds of type was very expensive, and of course such a work could not count upon as large a public as if it were a book of travel, and it did not sell very fast, even in spite of the tribute paid by critics to its usefulness. If I am not mistaken, it was in consequence of this circumstance that the same publisher did not take the second book in this field, and, besides, the publisher who did take it refused to let it be printed in such an expensive way. This second book on this question was the Gospel according to Matthew with its Parallels from Luke. As we have said, the way it is printed does not help make the matter plain, as was the case in the former book. Still it is a clear treatment of the new form of the problems and is at the same time a valuable commentary for the two gospels. No one who wishes to study the subject at length can afford to neglect the articles which Weiss contributed to the Jahrbiucher fiir deutsche Theologie in the years I 864 and 1865, and to the Theologische Studien und Kritiken in the year I866. In spite of the later books, these articles are not at all useless; they are still really necessary. A pamphlet of about twenty pages closed the books published while he was at Kiel. It was a discussion Of the Importance of Historical Considerations for the New Theology. 
Now comes the time for his full activity in the university of the capital of Germany. He entered upon his work at Berlin in the year I877, twenty years ago. It might be supposed that the large university, with the many calls of the large city upon the professor, would prevent his doing any more bookwork of importance. We shall see that that was not the case. He had scarcely taken root in Berlin before the volumes of Meyer's Commentary that he rewrought began to appear. We need not touch upon the single volumes. It will be enough to sum up this part of his work all at once. Its importance can only be understood by one who considers in what large numbers these volumes of Meyer's Commentary are scattered over the earth, for they are not at all confined to Germany. He took in hand the commentaries on Matthew, on Mark and Luke, on John, on the epistles of John, on the epistle to the Romans, on the epistles to Timothy and Titus, and on the epistle to the Hebrews. That is a task that might well satisfy a man for a number of years even if he had no lectures to give. Of the excellence of these commentaries it is not necessary to speak. Weiss had the courage finally to do away with the usual weak manner of patching up the writings of a dead scholar, and he remodeled the volumes, very much to the satisfaction of the users of them. We may say just here that he has begun to shake off this work, and has passed over the commentary on Mark and Luke to the care of his son, Professor Johannes Weiss of Marburg. In among all this he issued in the year I 882 his Life of Jesus, in two large volumes, and it reached a second edition in two years (the English edition, published by Clark, is in three volumes). This is the book which he dedicated, as we have said above, by a long letter, to his old friend Professor Georg Voigt. One point is worthy of note in regard to the Life of Jesus, namely, that Weiss here shows how well he can write a fluent style when the book calls for it. The present writer has heard men complain that Weiss's style, in his writings on Synopsis for example, was excessively dry. Dry? Do they suppose that scientific treatises are only good when they are clothed in a popular style? Weiss's books on Synopsis are not for the uneducated; they are for 
people who are intimately acquainted with the Greek Testament. And then, too, they are of necessity very much condensed. If he had aimed to make them popularly intelligent and pleasing, attractive, as the phrase runs, he would have had to make a dozen volumes of them and even then not give as much as he has given to the world of scholars. This Life of Jesus shows us Weiss in the character of a writer who can write easily and attractively. No wonder, then, that a third edition was called for in $\mathrm{I} 888$.

In the year I 886 Weiss published his Nerw Testament Introduction. On occasion of this book we may call attention to a leading trait of the author and of his writings. If this were a German article, this would be the place to put in the words subjective and objective. Weiss is extremely subjective in one way and that in general a very good way. Comparisons are odious or odorous, but I may venture to make one here, since the comparison will unfold the virtues of two great scholars at the same time. Professor Heinrich Julius Holtzmann of Strassburg has treated the New Testament almost as fully as Weiss, although he has done a world of other work in several directions. Now Holtzmann is in the particular in question "objective." The Introductions of these two scholars to the New Testament put these two qualities of writers before us in an unusually distinct manner, and this fact makes these two books really each a complement to the other. Holtzmann takes up the questions in an impersonal way and discusses the history of the case very minutely. He tells us what Augustine and Calvin and Luther, what Hilgenfeld and Holsten thought about the point in hand, and he is so little impressed with the fact that we care to know what Holtzmann thinks about it after he has studied all these views over, that he either does not say at all what he has finally decided upon as most likely, or he does it in such a modest and unobtrusive way that it is often as hard to find out his opinion on a question as it is to find a needle in a haystack. Weiss is the reverse in his habit of thinking and writing (and, we may add, of lecturing). For him everything is immediately interesting in the point of view that he himself 
takes of it. He never cares a fig for what anyone else says, if it does not commend itself to his mature judgment. In Holtzmann's Introduction you find out how the questions have been treated by all the world. In Weiss's Introduction you may find out something about the opinions of other people, but the main thing that you get is Weiss. Everything is for him a matter of course in the way that he sees it. Doubt is seldom necessary. There is in this style of thinking a certain fervor and incisive power that impresses itself upon the reader, when he is sure that the author understands the subject under discussion. Put this then down to the account of the personality and you have a weighty element in the sturdy make-up of this unwearying champion of New Testament truth.

As if we had not yet had enough, there is still another series of books to be mentioned in which our septuagenarian has presented, or we may say is still presenting, to the theological world the results of his researches in the New Testament. In the year I89I he published The Apocalypse of John: Text-Critical Studies, and Determination of the Text. Many a critic who saw the remarks upon the criticism of the text, in the numerous writings of Weiss, thought to himself in a self-satisfied way that Weiss had done all of this work on the text just as negligently as he himself was in the habit of doing his textual work. Indeed, once a scholar said to the present writer directly: "I suppose that Weiss when he decides about readings simply takes the Eighth Edition of Tischendorf and says to himself: "BCR and so forth are on the side of that reading and DEHS and so forth on the side of the other reading; the first is the reading that is to be chosen." By these words he intended to say that Weiss doubtless did not bother his head much about the readings, and did not know much about the manuscripts. He was surprised to hear that Weiss's notes on the text of the gospel of John alone filled a large pile of quarto leaves, on which the lightest deviations that could be of moment were carefully written down and compared. The critics who did not happen to hear thus privately of his work must have been stunned when they saw the book on the text of the Apocalypse. The first 156 
pages of it give a minute discussion of the readings and manuscripts, distinguishing between an older and a younger text and showing the relation of the most important manuscripts to the emended text. The rest (pp. I 57-225) offers the Greek text with brief philological notes. The Apocalypse was followed in the year 1892 by the Catholic Epistles, treated in the same manner. The book of Acts was issued in the year 1893. Thus far the textual criticism had been accompanied in the same volume by the text and a brief commentary that was merely intended to support the determinations of the text-critical discussions. Now, in the year 1896 , in the case of the Pauline epistles, a change has been made and the textual criticism of the Pauline epistles appears all by itself in a volume of iv and I6I pages. And then something altogether new, in form at least, is added in the totally independent volume entitled: The Pauline Epistles in the Corrected Text, with a Short Commentary for Handy Use in Reading the Scriptures. This volume contains vi and 682 pages. Before taking up the text-critical part of the matter it may be well to say a word or two about this new book.

For years the present writer has tried to persuade Professor Weiss to make a clear commentary of his own on the whole New Testament. At first he was urged to put into the Meyer series, on his own responsibility alone, all the New Testament books that he had not yet discussed in that series. This proved to be impossible. And still it was and is desirable that the world of theology have a complete display of the second part of Holy Writ as it presents itself to a scholar who has spent so many years upon its study. No one need hereupon think that the present writer has any wish to swear by the word of a set master. It is, without any regard to authority, of use to have a connected presentation of such a collection of writings from one practiced hand. It is desirable to be able to touch clearly Weiss without admixture with numerous other scholars. A glance at the work he has done upon the New Testament makes this plain. A Biblical Theology, an Introduction, and commentaries on the chief books must render him able to deal in an uncommonly fruitful way with what is left; and, more than that, must fit him to say what he 
thinks about each verse, independent of the constant intercalation of the view of a hundred other scholars. It will then be possible for each man who takes up the Weiss commentary to study the New Testament in all simplicity, to think for himself over against Weiss, instead of having a dozen contrasting views before him which almost of necessity preclude any healthy reaction of his own mind in reference to what Weiss suggests. It is high time that biblical scholars distinguish between exegesis and the history of exegesis, between the explanation of a given passage and the history of all the more or less sensible views that have ever been taken of the passage. If I am not mistaken, the tendency to make such collections of views and to add long lists of names for one view and another, has arisen partly from an often unconscious desire of commentators to see their names in the pages of every book upon the subject and to have them seen; a commentator has, for example, been known to cite all manner of other books without any regard to necessity but only upon the plan of touching every page which contained his own name. The commentary thus must serve the purpose of an advertising medium, a thing that does not in the least further biblical research. Another reason has been that commentators have felt bound to put down by every sentence the names of the men who had expressed a similar thought before. This is a misplaced honesty, and a totally unhistorical modesty. Were this method alone honest, no one could say "Two and two are four" without producing his predecessors in this most weighty statement. And modesty, thought of one's own self, should not come in here at all. It is a matter of business. The point is to explain Scripture, and that must be done purely and simply. Every special aid may receive mention in a preface, but the analysis of sentences must not be interrupted by the statement that $\mathrm{A}$ or $\mathrm{B}$ or $\mathrm{C}$ thinks thus and thus about it.

In this volume of Weiss's, which, as I write in October 1896 , has only just appeared, we have precisely what theological students and all who can read Greek need, for the cursory reading of the Pauline epistles. Pages I-I9 give an excellent short introduction with a summary of the historical points necessary 
to the understanding of the probable time and possible place of the origin of the epistles. No one will be surprised to see in this introduction that Weiss still finds no reasons to speak definitely about the authorship of the Pastoral Epistles. If some things in them are unlike the contents of the other letters of Paul, and if we do not know where to place them in the life of Paul, it is just as sure that we have not yet discovered a source in time, place, and author that offers to us fewer difficulties than the traditional source. "Therefore it is quite proper to try to explain these letters upon the supposition that they are, what they profess to be, letters from the unknown period of Paul's life after his release from the Roman imprisonment." That is enough about the volume in itself. All we need to add is the wish that Weiss give us precisely in the same form a commentary upon the gospels, the Acts, the catholic epistles, and the Apocalypse. Perhaps he could, with slight modifications, but better with none than not at all, simply cause for the Acts, Catholic Epistles, and the Apocalypse his brief commentary in the textcritical volumes above mentioned to be reprinted and sold separately for general use. I confess to one earnest wish, in case Weiss completes, as I hope, the commentary, namely, that the whole New Testament then be issued in the Greek order: Gospels, Acts, Catholic Epistles, Pauline Epistles, Apocalypse. It is greatly to be desired that some day in the dim future of nearer intercourse between all Christian churches we may reach the point of having our New Testaments throughout the world printed in the one order, and that the commonest older Greek order. The English version transposes the Catholic Epistles, and the German New Testament, in an altogether unjustifiable adherence to the consequences of Luther's arbitrary determinations about the canonical value of the books, mixes things up still more. External order is not to be compared to internal sense and contents, but it is nevertheless not to be neglected. If adherents of the other arrangements despise the value of order, then they may well let the old order be restored; it cannot matter much to them, and better is better.

Should Professor Weiss dislike to take up the gospels text- 
critically because he has already done so much synoptical work and has spent so much time both upon the text and the explanation of all four gospels, I should like to urge upon him the claims of the world to the complete short commentary above described. And in giving this short commentary he will at least give us, as in the case of the Pauline epistles, his mature determination of the text. If he can, however, go still further, and as for the Pauline epistles, present us a thorough text-critical discussion of the text of the gospels, thus completing also the textcritical treatment of the New Testament, I wish that he would combine with the textual criticism of the synoptists a brief treatment of the synoptic questions in an introduction and a continual reference all the way through to the various sources of the synoptic composition, as more or less certainly to be discerned.

Let us now turn to the textual criticism and especially to the latest volume of it, the Text Criticism of the Pauline Epistles. What little we have to say about this volume within the brief space allotted to us will suffice for our opinion in regard to all the textual volumes. A word may first be given to the reception of the previous volumes upon the text. On the one hand they have not been received with open arms, for the very simple reason that only an extremely limited number of theological scholars, whether professors or pastors or teachers, have gone so far into the study of the text as to be able to deal easily with such researches. Therefore the majority of scholars have not the courage to dive into the mass of detailed discussion of manuscripts and their readings. Happily the number of those who have learned to appreciate the value and the interest of such work is increasing, and philologians are waking up to the fact that the New Testament presents for them problems in palæographical research and in textual tradition such as are scarcely to be found in the whole range of non-biblical Greek literature. In the next place, some few scholars who have another way of looking at textual questions have rather disparaged Weiss's work. One, Paul Corssen of Berlin, the learned friend of Latin texts, attacked Weiss furiously in a long review in the Göttingen Gelehrte Anzeigen, I 893, No. I 5. Let me hasten 
to say that the "fury" was of no personal character. It is said and believed - I have not asked Corssen about it - that when he wrote the article he had not the remotest idea that it was the celebrated commentator against whom he was advancing. The zeal was altogether "scientific." Professor Weiss replied to the critics in a brief article in Hilgenfeld's Zeitschrift für wissenschaftliche Theologie, 37, 3, pp. 424-45 I.

The preface to this volume opens with a justification of his right to pursue his aims in textual criticism and to set them for himself according to his needs and to his powers. He emphasizes the fact that detailed exegesis has been his main point of interest and that he has been annoyed constantly in his work by the uncertainty of the text. He declares that neither the usual reasons of the commentators for determining the value of the various readings, nor the modern editions of the text appeared to offer him a satisfactory and certain path towards a decision. So he collected material year after year, grouped it now in this way and now in that, studied over it, and tried to open up for himself a path out of the difficulties. These collections and these studies are the basis of the textual volumes now before the public. Weiss is not in the least ignorant of the value of the many discussions already published by others, and as little does he forget the fact that a great deal still remains to be done to secure certainty touching the testimony of the manuscripts, and particularly of the versions and of the patristic quotations. $\mathrm{He}$ refers also to the need of verifying anew the collations in Tischendorf's apparatus. This is quite right. Tischendorf's apparatus must be verified anew, like every other apparatus. I should only like in passing to lay stress upon the fact, however, that the faults in Tischendorf's apparatus are not due to willful carelessness on his part. No one who has not tried to print sheet after sheet with countless detailed statements, and who has not then had the advantage of seeing the printed book verified in detail by a friendly, or better still by an unfriendly critic, has a thorough conception of the impossibility of securing infallible accuracy in such publications. Aware as Weiss is of all that must still be done for the apparatus, he still and quite 
correctly declares that exegesis with her daily needs cannot wait for the distant fulfillment of all such desires. It would indeed be the height of absurdity to insist upon anything of the kind, any delay of exegesis until textual criticism has completed its task perfectly; textual criticism will remain human, fallible, and imperfect so long as we remain men; the infallibility of the pope does not extend to the determination of the right readings in the Greek text of the New Testament. Therefore Weiss has taken up the work and trusts that, in spite of all deficiencies and disadvantages in the condition of the tradition of the text, he has been able to reach in almost all essential points a great degree of surety, and that in the rest he has at least reached a high degree of probability as a result of the work of years. Moreover, he is perfectly right when he asserts that even those who do not agree with him will find his disposition of the material and his discussion of it useful.

It is necessary to observe, before we go further, that after a brief introduction Weiss takes up the "exchange of words" of various classes, then "omissions and additions," then "changes in the positions of words," and finally "orthographical variations," and it is clear that these categories include almost all the various differences that are to be weighed. Everyone has his own logical fancies and the classes are not harmed by the above arrangement, but still I should have preferred an advance from more external to more internal variations and have put the trifles of orthography first, then the changes of position, then the changes of words, and finally the most radical things-the omissions and additions.

The brief introduction, pp. I-5, treats of the manuscripts. The text of the Pauline epistles is relatively well kept and the uncial manuscripts only have a little more than 6roo variations in 2000 verses. The codices KLP, with some further fragments, bring an emendated text. They have about 1250 errors peculiar to themselves, but the most of these errors are peculiar to the individual codices and only $\mathrm{I} 55$ are common to $\mathrm{K} \mathrm{L}$ and $\mathrm{P}$. A second group of codices DEFG gives both the Greek and the Latin text. Of these, $E$ is a copy of $D$, and $F$ and $G$ only represent 
one text, whatever the relation of the volumes to each other may be. $\mathrm{D}$ is the most weighty of this group. As for DE over against $\mathrm{FG}$, the points of agreement between the two pairs result from the fact that FG or their source were corrected according to a text which was the source of the errors in DE. A similar state of affairs is found when we compare these two groups KLP and DEFG together. They have about 460 errors in common and these spring not from a direct connection of one group with the other but from an older emendated text. The reader will please remember that an "emendated" text is not really an "unfaulted," "bettered," "corrected," and therefore "truly correct" text, but a text or a reading which somebody has in innocent ignorance changed, supposedly for the better, but actually for the worse. A colloquial German word, "Verschlimmbesserung" "badbettering," would be the appropriate term for such "emendation." If we pass on to the older codices, we find that $\aleph$ AB have also a large number of what we may call private errors, each for itself. $B$, the Vatican manuscript, has just as many errors of writing, specimens of carelessness, and arbitrary or thoughtless changes as $\boldsymbol{N}$ and $\mathrm{A}$, although it shares fewer errors with other codices. According to Weiss's judgment the right reading is found twenty times in the younger groups, $\boldsymbol{N}$ alone has the right reading only three times, $\mathrm{A}$ alone only once, where $\mathrm{B}$ is mutilated. $\mathrm{B}$ alone has the right reading eighty-five times. I dislike to copy this statement of Weiss's about $\mathrm{B}$, because I know how easily a reader is brought by such a curt statement to believe finally in the absolute preëminence of B ; still I let it stand as an expression of Weiss's opinion. So much for this interesting introduction.

When we turn to the following four divisions of variations that are discussed in full, we must of course repeat what the last sentence but one states for a special case. It is totally impossible for any scholar to find a positive standard of excellence for the readings. Had we such a standard, we should have the right text, which we as men can only ever tangentially approach without actually touching it. In consequence each scholar studies out for himself what may be the right read- 
ing in each case and then, by unalterable necessity, counts the faults or the virtues of the manuscripts according to the standard which he has himself set up. I see at this moment no cure for this. The only thing is that every reader of every critical work must remember that these groups of numbers endow the one who has counted them up, according to his own plan, with no infallibility. And here I touch one point that I fear is often forgotten by scholars, namely, that positively everybody, every single scholar who determines readings by the use of his brains, is "subjective," falls under this dreadful reproach. There is no help for it. The one thing for which there is help is that each man cease to imagine that by some special fiat of omnipotence he has himself succeeded in avoiding subjectivity, succeeded in getting outside of himself and in deciding with absolute impartiality precisely according to the testimony. He cannot do it. If a man imagined that he could avoid "subjectivity" by weighing the avoirdupois of the codices and letting the "divinely determined" weight upon the one side and the other settle the case, he would, precisely in the determination of this method of deciding, be the most crazily "subjective" of all.

Of course it is not desirable that we should here go at length into the details of the various readings as Weiss presents them. The reader must take the book in hand and delve for himself. The first division, the "Exchange of Words," fills pages 6-70, the "Omissions and Additions" pages 7I-127, the "Changes of Position" pages I $28-137$, and the "Orthographical Variations" pages 138-148. Pages 149-16I contain an index of the passages which are more fully treated. At this point the reader will be surprised to learn that Romans 9:5 does not appear in this list of passages, but he will then perceive the reason for the limitation we attached above to the completeness of the categories used by Weiss. Few New Testament scholars will fail to insist upon it that the passage in question is of great moment and that the critic of the text must say what he thinks about it. But punctuation is not found in those categories. I looked for it under "Orthographical" but in vain. It is of no 
avail for anyone to say that the oldest codices have no punctuation of importance. Our text is now edited by a textual critic and he must punctuate and he must know why he punctuates. Still, Weiss's view upon this point is clear from the commentary volume, and I do not in the least agree with him. I believe that after the manner of the larger number of Greek manuscripts we should put a full stop after ox́pкa. I believe that the doxology is one of the ejaculations addressed to God and that it is not connected, as a relative clause, with what goes before. That is my "subjective" opinion, just as Weiss's is his, only that I am inclined to consider the manuscripts as an "objective" support for my side.

If we turn to page 6, the first page of the "Exchanges of Words," we learn that $\theta$ cós and kúplos are most frequently exchanged, and it is an indication of the reserve shown by Weiss that he does not allude to the contracted forms $\overline{\Theta C} \overline{\mathbf{K C}}$ as doubtless influential in facilitating this exchange; Weiss wishes to speak as an exegete and not as a palæographer. This first case of exchange brings me to another external matter which I regret, namely, that the Greek is not accented. Greek may once in the manuscripts have been written without accents, but for centuries, for a thousand years, it has been written with them, and, what is more, it has never ceased in the living intercourse of ecclesiastical and civil life to be written with accents. To me, therefore, the practice of writing Greek without accents, is similar to the neglect to put on a coat, and I deprecate the growth of the practice in scientific works. This first page gives a specimen of the "subjective" certainty of the author. From the fact that $\theta$ cós occurs for kv́pos even in the oldest codices (I find it on the contrary strange that the change only occurs twice in $N$ ) and that in 2 Thess. $3: 3$ ADFG $7 \mathrm{I}$ and almost all Latin codices read $\theta$ cós instead of $\kappa$ ó "certain" conclusion that in 2 Tim. 2: I $4 \times$ CFG the Memphitic, a few minuscules, and the Latins have put $\theta$ cós for кv́pos, and although the author here differs from Tischendorf and from Westcott and Hort he does not give any further reason than the assimilation with two other passages. Now he may be 
right, but I do not know that he is right, and I certainly do

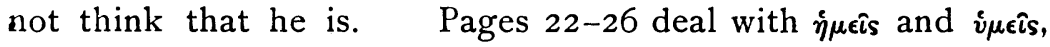
which, as Weiss says, are often changed in the codices in a way that makes no sense at all. It would be necessary for the palæographer to refer to the pronunciation as helping confound the words and to say that the variation in the case of single codices is scarcely worth discussing, and that, even where the codices stand favorably for one or the other, an exegete who has any really good reasons may riot in "subjectivity" without fear of the palæographers. Many a reader would have liked to see some discussion of the doxology and of its position at the end of the whole epistle as contrasted with the placing of it at the end of the fourteenth chapter. Doubtless Weiss was guided here by the large agreement between the uncial manuscripts. It is with me a question whether a clearer view of the textual condition of given books could not be secured by a discussion, prefaced or appended to the groupings given by Weiss, that should adjust itself more nearly to the "geography" of the book, a discussion that would be like a skeleton of the textual commentary perhaps, that would lay before us in a nutshell the condition of the text in chapter after chapter. Were some such addition before us, a casual or a new student would not stand so good a chance of running through the textual criticism, for example, of the epistle to the Romans without suspecting that Rom. 9: 5 or that the doxology were of peculiar interest. But we must stop picking flaws in this excellent book. The vast amount in which Weiss agrees with others need not be displayed at length. There is page after page that offers food for long study and reflection. Every page shows the great exactness of the author, whether he place before us the kaleidoscopic

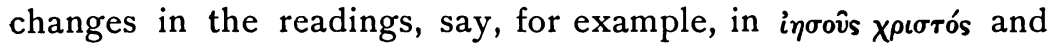

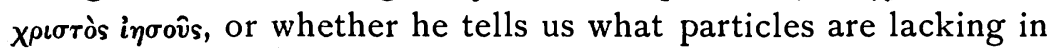
certain manuscripts.

Let us turn from the details of the book and glance at the whole. We need not lay stress upon the fact that perhaps too much is doubted, or upon the much more frequent fact that too much is settled with apodictic certainty. The book has one 
point of great value, is in itself, in its existence, of vast importance for the science of textual criticism. Thus far, for decade after decade, we have heard the changes rung upon the theme: "Textual critics are subjective in their decisions." And this phrase has come to be as certain as the mewing of cats and the milk-giving of cows. Exegetes have in general viewed the battle of varying readings from afar. They have only noted here and there, usually at second or at tenth hand, an event or so from the fray, and have comforted their souls that they were absolutely impartial, and the necessary inference was that if they by any chance became critics, that if any exegete by any revolution of fate became a critic of the text, the state of affairs would be changed; subjectivity would cease and all would be as in the best of worlds. How often have I heard the words : "If Tischendorf had only been an exegete, he would have decided otherwise." Now in Weiss we have an exegete of the first order, one who of course as an exegete has his opponents, but one whose very opponents by their own high rank declare to be a prince. And Weiss has entered upon the field of textual criticism. He has not taken up palæography as Tischendorf did, and he has not gone into reading consecutively and collating published manuscripts, or the works of the fathers, as Westcott and Hort did, but he has taken the variations noted by others, and has with the most unwearying zeal, with unsparing diligence, with ceaseless toil, for many years studied the text. I insist upon it that the text of the New Testament determined upon by such a man, with such preparation, is an event in the history of textual criticism, and I wish that his text could be printed in a handy edition by itself so that everyone could conveniently refer to the text of an exegete. It is perfectly true that in respect to a large number of passages I do not agree with Weiss. But then I am not infallible. $\mathrm{He}$ may be right. And at any rate it is well to know what fits his "New Testament sense," for one who has so long studied the New Testament should have some special intuitions at last guiding him to the right issue.

The one circumstance which is a comfort for textual critics 
who are not exegetes, much as it may be a pity for the New Testament text, is the outflow of what we have said above about human or scholarly subjectivity. Weiss is one of the most subjective of men, that is to say, he is a strong character and no prattler; he is never lukewarm, rarely uncertain. What he sees is what is to be seen. He needs no chromatic correction. And of course this shows itself in his decisions upon the text. His reasons for accepting or rejecting given readings are precisely the same kind of reasons that have been used before. He has not discovered a new theory of perception that prevents subjectivity. He has not entered a fourth dimension that places him above his predecessors. He only applies the reasons in another way in the given case.

In this glance at Weiss's newest books we have for the nonce lost the thread of our contemplation of his person as a whole. We have come down to details and in these details we have shown that to love and to honor him is quite compatible with disagreement, with failure to agree with him, in given scientific determinations. Let us return to the man. We have seen how much he has written, and the reader will imagine for himself what hours of patient labor, what incessant occupation with the New Testament, the books we have counted up must have demanded for their production. Nevertheless the tale is not complete without another page. The student who was so devotedly attached to Wichern, who began then to work for "Inner Mission," finds his counterpart in the man who year by year, now in one city, now in another, marshals in a congress for Inner Mission for all Germany the ever-growing throng of those who apply themselves to this work. From textual criticism to Inner Mission seems to some men to be a long stride. He who takes up exegesis and textual criticism because the New Testament is to him the Book of Books cannot fail to have a heart for the people, cannot fail to have a fountain of mercy in his heart that flows for the people. When you think of Bernhard Weiss as a severe scholar do not forget that he has a warm heart. 
Our picture in its hasty, rude lines is nearly done. The daily professional activity and the official activity as ministerial counselor are all that remains to be spoken of, and these two activities, important as they are, seem trifling after what we have already said. Take the latter first. For the ministry of worship he has to attend to all that concerns the appointing of professors of theology in the numerous universities of Prussia. At any moment he may have to let his work drop and go off to Giessen or to Basel or to Bern, anywhere, and see what a privatdocent or a professor is like. He listens to a lecture or two and if possible attends a seminary exercise and then reports at Berlin for or against the candidate, as the case may be. While at home he of course must often go to the minister, for there is scarcely ever a time at which some theological professorship is not waiting to be filled. As for the lectures, they are of the usual amount and variety for a German professor, embracing a number of topics. The summer term for 1896 was filled up by him with lectures on the Biblical Theology of the New Testament five hours each week, on the Epistle to the Romans four hours, on the Passion one hour, and to that must be added once a week the exercises of the New Testament seminary. During the present winter term, I896-7, he lectures five hours a week on New Testament Introduction and five hours on the Synoptic Gospels. Weiss lectures in the same decisive way in which he thinks and writes. He does not doubt his results, and he gives them with firmness.

May the vigor that Professor Weiss now shows in his seventieth year be long continued to him, and may his happiness in his home and in his work increase as the years flow on ! 